\title{
Rat small intestinal morphology and tissue regulatory peptides: effects of high dietary fat
}

\author{
By F. A. SAGHER ${ }^{1}$, J. A. DODGE ${ }^{1 *}$, C. F. JOHNSTON ${ }^{2}$, C. SHAW ${ }^{2}$, \\ K. D. BUCHANAN ${ }^{2}$ AND K. E. CARR ${ }^{3}$ \\ Departments of ${ }^{1}$ Child Health, ${ }^{2}$ Medicine and ${ }^{3}$ Anatomy, The Queen's University of Belfast, \\ Grosvenor Road, Belfast BT12 6BJ, Northern Ireland
}

(Received 24 July 1989 - Accepted 8 August 1990)

\begin{abstract}
Sprague-Dawley rats ( 3 weeks old) were fed on isoenergetic diets in which $40 \%$ of the total energy was provided as fat either in the form of butter (high saturated fat), olive oil (high monounsaturated fat) or maize oil (high polyunsaturated fat), with one group on low-fat (10\% of total energy) standard diet as a control. Animals were killed after 8.4 (se 0.8) weeks by cardiac puncture. Similar pieces of jejunum and ileum were prepared for morphometric studies. Extracts of tissue from the proximal and distal segments of the whole small intestine from four animals per group were assayed using established techniques for enteroglucagon, motilin, neurotensin, somatostatin, substance $P$ and vasoactive intestinal peptide (VIP). We found that maize oil and olive oil increased villus height : crypt depth ratio in both jejunum and ileum. Maize oil increased tissue concentrations of somatostatin $(P<0.05)$ and substance $P(P<0.005)$ in the proximal segment. Both maize oil and olive oil increased tissue concentrations of neurotensin and substance $P(P<0$-005) in the distal segments. These observations may explain the improvement of intestinal absorption of fluid following supplementation with polyunsaturated fat.
\end{abstract}

Small intestinal morphology: Gut peptides: Rat

Numerous studies have been reported relating the response of the small intestinal morphology to alteration in the feeding pattern (Fabry \& Kujalove, 1960), subnutrition (Hindmarsh et al. 1967), starvation (Hopper et al. 1968) and hyperphagia (Brownlee \& Moss, 1959). They demonstrated that the gut mucosa is remarkably sensitive to alteration in its microenvironment, starvation markedly affecting the epithelial renewal of rat duodenum (Hooper \& Blair, 1956) and food stimulating cell proliferation in the epithelial crypt of the small intestine (McManus \& Isselbacher, 1970). However, there are very few reports on the specific effects of dietary fat on small intestinal morphology. It is likely that any such effects are mediated by 'regulatory' peptides.

There are several circulating peptides released in response to feeding which have been demonstrated in high concentration in gut tissue (Schultzberg et al. 1980) and have been shown to be essential for normal intestinal and pancreatic functions (Adrian \& Bloom, 1985).

Six peptides were chosen for study on the basis of their possible release by fat and their influence on one or more of the following intestinal functions: intestinal cell proliferation, local mucosal immunity, ion transport and intestinal motility. They were enteroglucagon, motilin, neurotensin, somatostatin, substance $P$ and vasoactive intestinal peptide (VIP).

\footnotetext{
* For reprints.
} 
Table 1. Composition of the basic diet $(\mathrm{g} / \mathrm{kg}$ complete diet)

\begin{tabular}{|c|c|c|}
\hline & $\begin{array}{c}\text { Control } \\
\text { (low-fat diet) }\end{array}$ & High-fat diet \\
\hline Fat & 35 & $200^{*}$ \\
\hline Protein & $173 \cdot 2$ & 200 \\
\hline Carbohydrate & 549 & 500 \\
\hline Vitamin mix & $11 \cdot 3$ & 20 \\
\hline Salt mix & $43 \cdot 2$ & 40 \\
\hline Fibre (non-nutritive) & 31 & 40 \\
\hline
\end{tabular}

* In the high-fat diet, the fat consisted of olive oil (high in monounsaturated fatty acids), butter (high in saturated fatty acids) or maize oil (high in polyunsaturated fatty acids).

Table 2. Fatty acid profile of diets*

\begin{tabular}{|c|c|c|c|c|}
\hline \multirow{2}{*}{$\begin{array}{l}\text { Diet... } \\
\text { Fatty acid }\end{array}$} & \multicolumn{3}{|c|}{ High-fat $(200 \mathrm{~g} / \mathrm{kg})$} & \multirow{2}{*}{$\begin{array}{c}\text { Low-fat } \\
(35 \mathrm{~g} / \mathrm{kg})\end{array}$} \\
\hline & Olive oil & Butterfat & Maize oil & \\
\hline $6: 0$ & - & 0.28 & - & - \\
\hline $8: 0$ & - & $0 \cdot 86$ & - & 一 \\
\hline $10: 0$ & - & $2 \cdot 32$ & - & - \\
\hline $12: 0$ & - & $2 \cdot 89$ & 一 & - \\
\hline $14: 0$ & $0 \cdot 12$ & $17 \cdot 02$ & $0 \cdot 26$ & 0.57 \\
\hline $14: 1$ & - & $1 \cdot 32$ & - & - \\
\hline $15: 0$ & - & $1 \cdot 21$ & - & - \\
\hline $16: 0$ & $9 \cdot 22$ & $31 \cdot 25$ & $8 \cdot 46$ & $13 \cdot 87$ \\
\hline $16: 1$ & - & $1 \cdot 72$ & $\ldots$ & - \\
\hline $17: 0$ & - & $0 \cdot 86$ & - & - \\
\hline $18: 0$ & $2 \cdot 94$ & $10-38$ & $1 \cdot 76$ & $2 \cdot 15$ \\
\hline $18: 1$ & $79 \cdot 36$ & $24 \cdot 58$ & $29 \cdot 78$ & $22 \cdot 51$ \\
\hline $18: 2 n-6$ & 6.99 & $2 \cdot 39$ & $57 \cdot 78$ & $54 \cdot 13$ \\
\hline $18: 2 n-3$ & 0.89 & 0.58 & 1.97 & $6 \cdot 28$ \\
\hline $20: 1$ & - & - & - & - \\
\hline Others & - & $1 \cdot 84$ & - & - \\
\hline Saturated & $12 \cdot 28$ & $67 \cdot 57$ & $10 \cdot 48$ & 16.59 \\
\hline Monounsaturated & $80 \cdot 16$ & $27 \cdot 62$ & $29 \cdot 78$ & $23 \cdot 01$ \\
\hline Polyunsaturated & $7 \cdot 88$ & $2 \cdot 97$ & $59 \cdot 75$ & $60 \cdot 4 !$ \\
\hline
\end{tabular}

* Diets were analysed by the Department of Food Biochemistry, Faculty of Agriculture, The Queen's University of Belfast, Belfast.

\section{METHODS}

Diet

The basic diet contained $200 \mathrm{~g}$ fat $/ \mathrm{kg}$, which provided $40 \%$ of the total energy as fat, in the form of butter (high in saturated fatty acids), olive oil (high in monounsaturated fatty acids) or maize oil (high in polyunsaturated fatty acids) (Table 1). The diets were isoenergetic and nutritionally adequate, providing for all known essential requirements (Special Diet Service, Witham, Essex). The only variables were the degree of fat saturation and the $n-6: n-3$ fatty acid ratio (Table 2). A fourth (control) group was fed on a low-fat ( $10 \%$ of energy) standard diet supplied by Robert Morton \& Company Ltd, Ballymena, Co. Antrim.

\section{Animals}

Fifty-nine Sprague-Dawley rats were individually housed and weaned from the age of 3 weeks on to one of three synthetic diets, fourteen on butter, nineteen on olive oil, twelve 
on maize oil, and fourteen on the control diet. To reduce coprophagy, the animals were kept in cages with wire mesh bottoms, and they were subjected to $12 \mathrm{~h}$ alternate darkness and light. Their intake was calculated daily. After 8.4 (SE 0.8) weeks, rats were anaesthetized by sodium pentobarbitone $(60 \mathrm{mg} / \mathrm{kg})$ intraperitoneally and killed by cardiac puncture.

\section{Small intestinal morphometric studies}

Similar segments of jejunum and ileum were removed gently from the mesenteric border and processed for light microscopy. Each segment was fixed in $10 \%$ formal saline ( $9 \mathrm{~g}$ sodium chloride/1), dehydrated, cleared and embedded in paraffin wax. The segments were cut at $5 \mu \mathrm{m}$ and stained using haematoxylin and eosin. A total of 100 villi and 100 crypts were studied from each group (three sections per region and three animals per group).

The villus height and crypt depth were measured using computer-aided microscopy (Slavin et al. 1980; Challacombe et al. 1983).

The villus height was measured (only in villi attached to lamina propria) as the distance between the upper border of muscularis mucosa and the tip of each villus structure seen in the slide. The crypt depth was measured as the distance between the open mouth of a crypt in the section through the centre of the crypt to the basement membrane zone at the basis of the crypt (Slavin et al. 1980).

\section{Tissue regulatory peptides}

The whole small intestine was removed from four animals of each group, freed from the mesentery, divided into two equal proximal and distal segments and stored at $-20^{\circ}$.

Each segment was extracted separately by an acid-alcohol method in $0.4 \mathrm{M}$-phosphate buffer, pH 7.4 (Bryant \& Bloom, 1982) before measurement of individual peptides by radioimmunoassay. Each sample was assayed for each gut peptide in duplicate, the average of which was taken as representative of the tissue concentration in each rat.

VIP. Natural porcine VIP was used as standard. Antibodies to VIP were raised in New Zealand white rabbits. The assay can detect $5 \mathrm{ng} / 1$ with $95 \%$ confidence and is sensitive over a range $0-300 \mathrm{ng} / 1$. There is no cross-reactivity in the assay with glucagon, secretin or gastric inhibitory peptide (GIP) and the antibody is predominantly C-terminal reactive (Ardill, 1979).

Somatostatin. The standard was synthetic cyclic somatostatin (Serono). The antibody OB5 (1) was raised in rabbits to cyclic somatostatin. No cross-reactivity with any other gut or islet peptide was found. The antibody is C-terminally directed, although reaction with fragments is low, suggesting that the whole molecule is required for full cross-reactivity. The assay can detect $3 \mathrm{ng} / \mathrm{l}$ with $95 \%$ confidence.

Motilin. The standard was synthetic porcine motilin. The antibody was raised in rabbits and cross-reacts $100 \%$ with porcine motilin. It does not cross-react with C-peptide, VIP, gastrin, GIP, glucagon or insulin. The assay can detect $10 \mathrm{ng} / 1$ with $95 \%$ confidence.

Enteroglucagon. The antibody used in the assay was YY 57 raised in rabbits. The antibody reacts with the $\mathrm{N}$-terminal region of glucagon (Flanagan et al. 1974). This antibody can detect $5.9 \mathrm{ng} / 1$. No cross-reactivity has been noted with other gut and islet hormones including secretin, VIP, GIP, insulin, motilin, cholecystokinin and gastrin.

Neurotensin. The standard was synthetic neurotensin (Bachem Torrance, CA, USA). The antibody NT3 was raised in New Zealand rabbits (Shaw \& Buchanan, 1983). This antibody reacts with the whole molecule. It detects $3 \mathrm{pmol} / 1$ with $95 \%$ confidence and exhibits no cross-reactivity with other regulatory peptides.

Substance $P$. The standard was synthetic substance P (Bachem Torrance, CA, USA). The antibody GSP 10 was raised in guinea-pigs. It reacts with the $\mathrm{C}$-terminal region. The antibody can detect $0.2 \mathrm{pg} /$ assay tube with $95 \%$ confidence. It cross-reacts $(1 \%)$ with neurokinin $\mathrm{A}$ and neurokinin $\mathrm{B}$. 


\section{Statistical analysis}

One-way analysis of variance (ANOVA) was used throughout. Unpaired Student's $t$ test was used to analyse the statistical significance of the differences between the mean values of villus heights and crypt depths in each group compared with controls.

The results on regulatory peptides were not normally distributed so for these the nonparametric one-way analysis of variance (Kruskal-Wallis) and the Mann-Whitney U test were used. The results are reported as median and range.

\section{RESULTS}

\section{Characteristics of animals}

The weight of the animals at the start and at the end of the feeding period, their daily intake and the duration of feeding did not significantly differ among the four dietary groups (Table 3).

\section{Dietary fat and small intestinal morphology}

Feeding rats on high dietary fat altered the basic morphology of the small intestine (Table 4). Maize oil increased the villus height in both jejunum and ileum $(P<0-001)$. Olive oil markedly increased the villus height in jejunum and ileum $(P<0.001)$ and decreased the crypt depth in jejunum $(P<0.05)$ and ileum $(P<0.05)$. Butterfat markedly reduced the villus height in jejunum $(P<0.01)$ and ileum $(P<0.05)$ and reduced the crypt depth in both jejunum $(P<0.001)$ and ileum $(P<0.01)$.

\section{Dietary fat and tissue regulatory peptides}

There were no statistically significant differences in tissue VIP and motilin.

Comparing the proximal with the distal segments in each group, we found that the tissue concentrations of enteroglucagon were significantly higher distally in the control group $(P<0.05)$, in the olive oil group $(P<0.001)$ and in the maize oil group $(P<0.025)$. Neurotensin was significantly higher distally in the maize oil $(P<0.01)$ and in the olive oil $(P<0.001)$ groups.

Maize oil significantly increased the proximal small intestinal tissue concentration of substance $\mathrm{P}(P<0.001, v$. control $)$ and somatostatin $(P<0.05, v$. control $)$.

Both maize oil and olive oil increased distal small intestinal tissue concentrations of substance $\mathrm{P}$ and neurotensin $(P<0.001, v$. control $)$. Butterfat did not significantly alter the tissue concentration of any of the six peptides investigated (Table 5).

\section{DISCUSSION}

The simultaneous occurrence of endocrine, paracrine and neurocrine functions of the gut peptide cells makes it difficult to judge the local activity of these cells only by estimation of plasma levels of the different peptides. Measurement of the total tissue concentration of gut peptides may serve to evaluate the possible effects of dietary fat on the potential release of these peptides with local paracrine and neurocrine functions.

Gut peptides are contained in the granules of neurones and endocrine cells and stimulated from the lumen side to be released locally and into the circulation. Accordingly, composition, load, transport, digestion and absorption of food would be expected to influence the release of tissue peptides. The pattern of feeding ad lib. in the present study might be expected to eliminate the surges of peptide release that follow set meals, but correspondingly makes it impossible to determine specific effects of dietary variation in individual meals.

There were no significant effects of dietary fat on small intestinal tissue concentration of enteroglucagon, motilin and VIP. Single mixed meals are known to release more 
Table 3. Food intake $(\mathrm{g} / \mathrm{d})$ and weights $(\mathrm{g})$ of rats fed on a control low-fat $(35 \mathrm{~g} / \mathrm{kg})$ and three high-fat $(200 \mathrm{~g} / \mathrm{kg})$ diets from the age of 3 weeks

\begin{tabular}{llccccc}
\hline Diet & $\begin{array}{c}\text { No. of } \\
\text { rats }\end{array}$ & $\begin{array}{c}\text { Wt at } \\
3 \text { weeks }\end{array}$ & $\begin{array}{c}\text { Weeks on } \\
\text { experiment }\end{array}$ & $\begin{array}{c}\text { Final } \\
\text { wt }\end{array}$ & $\begin{array}{c}\text { Food } \\
\text { intake }\end{array}$ \\
\hline Control & 14 & 42.1 & 8.4 & 277 & Ad lib. \\
High-fat & & & & & \\
Butterfat & 14 & 40.5 & 8.2 & 270 & 16.5 \\
Olive oil & 19 & 38.3 & 8.4 & 289 & 16.7 \\
Maize oil & 12 & 40.4 & 8.6 & 309 & 18.7 \\
SD (55 d) & & 6.06 & 2.41 & 75.8 & $2.73^{*}(42 \mathrm{df})$ \\
\hline
\end{tabular}

Table 4. Mean villus heights and crypt depths (um) of rats fed on a control low-fat $(35 \mathrm{~g} / \mathrm{kg})$ and three high-fat $(200 \mathrm{~g} / \mathrm{kg})$ diets from the age of 3 weeks

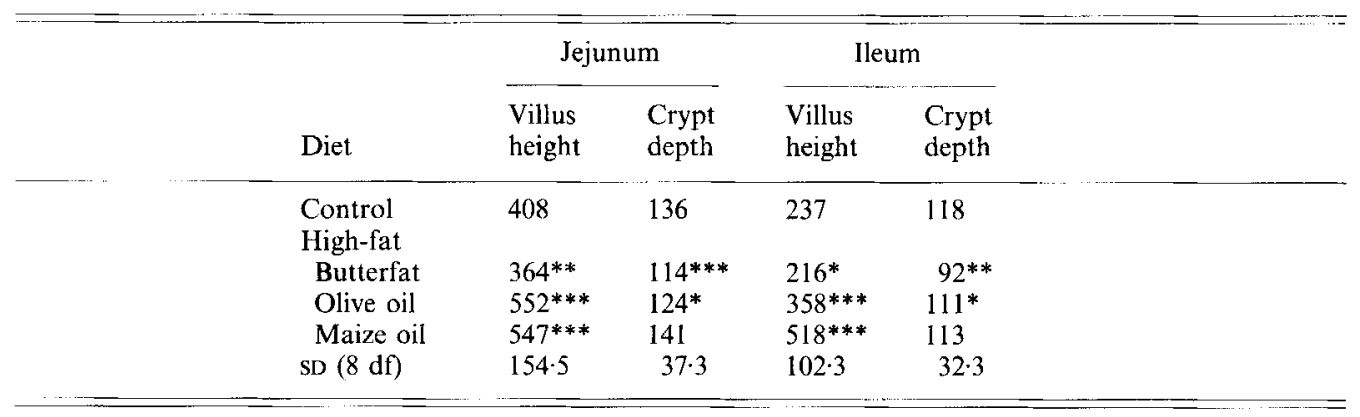

Mean values were significantly different from those for control group: ${ }^{*} P<0.05,{ }^{* *} P<0.01,{ }^{* * *} P<0.001$.

enteroglucagon than cream or glucose alone (Ghatei \& Bloom, 1981). Both test mixed meals and oral fat stimulate the release of motilin (Christofides et al. 1979) and intraduodenal acid (not mixed meal, nor oral or intravenous glucose) increases plasma VIP (Long \& Bryant, 1982). It may be that, despite low tissue levels, the lumen or circulating levels of these peptides were elevated as they were quickly released by the diet.

However, dietary fat as maize oil markedly increased the tissue concentration of somatostatin and substance $P$ in the proximal segment of the small intestine. Both peptides have dual paracrine and neurotransmitter functions. Somatostatin is released from D cells in the duodenum, whose morphology and direct contact with putative effector cells suggest that they deliver somatostatin directly onto the membranes of these cells. It has been found that substance $P$ and somatostatin present in gut are able to modulate immune functions, and receptors for these peptides were found on lymphocytes (Stanisz et al. 1986). Since their concentration is higher in tissue than in plasma, it is possible that they may be important immunoregulatory factors (Stanisz \& Bienenstock, 1986).

Neurotensin is predominantly found in the distal segment of the small intestine (Solcia et al. 1978; Carraway et al. 1976) and fat seems to be the most important nutrient in a meal in terms of effect on its release (Shaw et al. 1986; Rosell \& Rokaeus, 1979). Lumen fat is required for neurotensin release since intravenous administration of an oily emulsion in the same oral dose did not influence the concentration of immunoreactive neurotensin in blood. Presumably neurotensin is released when neurotensin-containing cells ( $\mathrm{N}$ cells) in the small intestine are exposed to the ingested fat (Rosell, 1982).

Intraduodenal administration of small amounts of oleic acid results in an increased 
Table 5. Concentrations ( $\mathrm{pg} / 10 \mathrm{ml}$ per $\mathrm{g}$ wet tissue) of small intestinal gut peptides in rats fed on a control low-fat $(35 \mathrm{~g} / \mathrm{kg})$ diet and three high-fat $(200 \mathrm{~g} / \mathrm{kg})$ diets from the age of 3 weeks

\begin{tabular}{|c|c|c|c|c|c|c|c|c|c|c|c|c|}
\hline \multirow[b]{3}{*}{ Diet } & \multicolumn{12}{|c|}{ Proximal } \\
\hline & \multicolumn{3}{|c|}{ Substance $\mathrm{P}$} & \multicolumn{3}{|c|}{ Neurotensin } & \multicolumn{3}{|c|}{ Enteroglucagon } & \multicolumn{3}{|c|}{ Somatostatin } \\
\hline & Med.* & Min. & Max. & Med. & Min. & Max. & Med. & Min. & Max. & Med. & Min. & Max. \\
\hline Control & $0 \cdot 41$ & 0.32 & 0.73 & 1.8 & 1.5 & $3 \cdot 7$ & 37.0 & $33 \cdot 3$ & 111 & $12 \cdot 9$ & $7 \cdot 3$ & $18 \cdot 7$ \\
\hline Butterfat & 0.47 & $0 \cdot 10$ & 0.70 & $3 \cdot 3$ & 0.7 & $12 \cdot 2$ & 91.0 & $28 \cdot 8$ & 182 & $22 \cdot 6$ & $2 \cdot 9$ & $37 \cdot 2$ \\
\hline Olive oil & $0 \cdot 50$ & 0.40 & $0 \cdot 70$ & $3 \cdot 8$ & $1 \cdot 3$ & $7 \cdot 2$ & $55 \cdot 6$ & $40 \cdot 7$ & 104 & $19 \cdot 0$ & $7 \cdot 3$ & $47 \cdot 0$ \\
\hline Maize oil & $0 \cdot 72$ & 0.69 & 1.80 & $9 \cdot 3$ & $3 \cdot 3$ & $20 \cdot 5$ & $51 \cdot 3$ & $30 \cdot 6$ & 125 & $25 \cdot 1$ & $16 \cdot 7$ & $55 \cdot 5$ \\
\hline \multirow{4}{*}{ Maize oil } & & & & & & & & & & & & \\
\hline & \multicolumn{3}{|c|}{$<0-001$} & \multicolumn{3}{|c|}{$>0.05$} & \multicolumn{3}{|c|}{$>0.05$} & \multicolumn{3}{|c|}{$<0.05$} \\
\hline & \multicolumn{6}{|c|}{ Distal } & & & & & & \\
\hline & \multicolumn{3}{|c|}{ Substance $\mathbf{P}$} & \multicolumn{3}{|c|}{ Neurotensin } & \multicolumn{3}{|c|}{ Enteroglucagon } & & & \\
\hline Diet & Med. & Min. & Max. & Med. & Min. & Max. & Med. & Min. & Max. & & & \\
\hline Control & $0 \cdot 46$ & $0 \cdot 26$ & 0.51 & $3 \cdot 4$ & 0.08 & 6.9 & 114 & $44 \cdot 3$ & 171 & & & \\
\hline Butterfat & $0 \cdot 31$ & $0 \cdot 10$ & 0.40 & 46 & $2 \cdot 2$ & $11 \cdot 1$ & 121 & $64 \cdot 5$ & 206 & & & \\
\hline Olive oil & $0 \cdot 60$ & 0.35 & 0.70 & $8 \cdot 8$ & $7 \cdot 7$ & 14.5 & 206 & 111.8 & 253 & & & \\
\hline Maize oil & 0.90 & 0.80 & $1 \cdot 30$ & $21 \cdot 4$ & $15 \cdot 2$ & $50 \cdot 0$ & 132 & $68 \cdot 3$ & 236 & & & \\
\hline \multicolumn{13}{|l|}{ Differences $\dagger$} \\
\hline Olive oil & \multicolumn{3}{|c|}{$<0.001$} & \multicolumn{3}{|c|}{$<0.001$} & \multicolumn{3}{|c|}{$>0.05$} & & & \\
\hline Maize oil & \multirow{2}{*}{\multicolumn{3}{|c|}{$<0.001$}} & \multirow{2}{*}{\multicolumn{3}{|c|}{$<0.001$}} & \multicolumn{3}{|c|}{$<0.05$} & & & \\
\hline Differences & & & & & & & & & & & & \\
\hline Control & \multicolumn{3}{|c|}{$>0.05$} & \multicolumn{3}{|c|}{$>0.05$} & \multicolumn{3}{|c|}{$<0.05$} & & & \\
\hline Olive oil & \multicolumn{3}{|c|}{$>0.05$} & \multicolumn{3}{|c|}{$<0.001$} & \multicolumn{3}{|c|}{$<0.001$} & & & \\
\hline Maize oil & \multicolumn{3}{|c|}{$>0.05$} & \multicolumn{3}{|c|}{$<0.01$} & \multicolumn{3}{|c|}{$<0.05$} & & & \\
\hline
\end{tabular}

* Medians and ranges are given because the data are not normally distributed. Non-parametric tests (Kruskal-Wallis and Mann-Whitney $\mathbf{U}$ test) were used to determine the significance of differences between diet groups and between the proximal and distal regions of the small intestine.

$\dagger$ Significance of difference from control group, $P$ : values not quoted in the table are all $>0.05$.

+ Significance of differences between proximal and distal regions of the small intestine, $P$ : probabilities for the butterfat diet are all $>0.05$.

plasma concentration of neurotensin, which is dose-responsive (Kihl et al. 1981). The plasma levels of neurotensin after oral administration of an amino acid mixture or oleic acid were higher than after glucose or saturated fat (Ito et al. 1982). The present study agrees with the previous observations and demonstrates that linoleic acid in maize oil is more potent than oleic acid in olive oil in terms of increasing distal small bowel tissue concentrations of both neurotensin and substance $P$.

The tissue concentration of substance $P$ in the distal segments followed the same pattern as neurotensin. Whether their total endocrine cell mass is increased or whether neurotensin stimulates the formation of more substance $P$ via neuronal mechanisms is not clear.

Descriptive observations based on visual assessment of mucosal sections are not sufficient and objective measurements are required to detect any changes in small intestinal morphology produced by dietary fat. Villi are taller proximally than distally (Kapadia \& Baker, 1976) even after feeding high dietary fat, with the exception of the group fed on high polyunsaturated dietary fat in which the villus height in the ileum was not far different from that in the jejunum. 
The crypt depth was increased proximally to a greater extent than distally as shown by some authors (Clarke, 1975; Thomson et al. 1986) but not others (Kapadia \& Baker, 1976).

Small quantities of long-chain triacylglycerols ( $20 \%$ of total energy intake) promote mucosal growth equal to a complete macromolecular diet (Robinson \& Dowling, 1982), and free fatty acids are even more effective than long-chain triacylglycerols (Grey et al. 1984). Short-chain fatty acids (acetic, propionic and butyric acids) are not only major products of fermentive digestion by intestinal micro-organisms but are also a physiological lumen trophic factor for the intestinal mucosa (Miazza et al. 1985).

Whether the unsaturated dietary fat produces any biochemical changes that allow the epithelial cells of the jejunum and ileum to survive longer than those exposed to the saturated-fat or low-fat diet remains unclear. Whether the enterocyte life span is determined by their being pushed off the tip of the villus (Clarke, 1977) or whether the final shape of the villi is a result of variation in cell production (Creamer, 1964) requires further studies. However, these observations may explain some of our previous results on the effects of high dietary fat on water and ion transport during in vivo jejunal perfusion studies, because rats fed on a diet high in polyunsaturated fat had both the tallest villi and the best absorption (Sagher, 1988; Sagher et al. 1990). However, enteroglucagon is usually regarded as the most important of the gut peptides known to have trophic effects, but the lack of effect on enteroglucagon levels in the present study suggests that it was not the agent responsible for increased villus growth in response to unsaturated fat.

Many thanks are due to the technicians in the Wellcome Research Laboratory, Department of Medicine and in the Department of Anatomy, The Queen's University of Belfast for their technical help and advice.

\section{REFERENCES}

Adrian, T. E. \& Bloom, S. R. (1985). Effect of food on gut hormones. In Food and the Gut, pp. 13-29 [J. O. Hunter and V. A. Jones, editors]. London: Baillière Tindall.

Ardill, J. (1979). Radioimmunoassay of gastrointestinal hormones. In Clinics in Endocrinology and Metaholism, vol. $8: 2$, pp. $265-280$ [K. D. Buchanan, editor]. London: W. B. Saunders.

Brownlee, A. \& Moss, A. (1959). Changes in size of the gastrointestinal tract, liver and kidneys of the laboratory rat at different liver weight and on different dietary regimes. British Veterinary Journal 115, 225- 234.

Bryant, M. G. \& Bloom, S. R. (1982). Measurement in tissues. In Radioimmunoassay of Gut Regulatory Peptides, pp. 38-42 [S. R. Bloom and R. G. Long, editors]. London: W. B. Saunders.

Carraway, R. \& Leeman, S. E. (1976). Characterization of radioimmunoassayable neurotensin in the rat: its differential distribution in the central nervous system, the small intestine and stomach. Journal of Biological Chemistry 251, 7045-7052.

Challacombe, D. N., McDonald, D. T. \& Wheeler, E. E. (1983). A quantitative assessment of jejunal villous damage in coeliac disease, using the mucosal index. Hepato-Gastroenterology 30, 113-115.

Christofides, N. D., Bloom, S. R., Besterman, H. S., Adrian, T. E. \& Ghatie, M. A. (1979). Release of motilin by oral and intravenous nutrients in man. Gut 20, 102-106.

Clarke, R. M. (1975). Diet, mucosal architecture and epithelial cell production in the small intestine of specifiedpathogen-free and conventional rats. Laboratory Animals 9, $201-209$.

Clarke, R. M. (1977). The effects of age on mucosal morphology and epithelial cell production in rat small intestine. Journal of Anatomy 123, 805-811.

Creamer, B. (1964). Variations in small intestinal villous shape and mucosal dynamics. British Medical Journal ii, 1371-1373.

Fabry, P. \& Kumalove, V. (1960). Enhanced growth of the small intestine in rats as a result of adaptations to intermittent starvation. Acta Anatomica 43, 264-271.

Flanagan, R. W. J., Buchanan, K. D. \& Murphy, R. F. (1974). Specificity of antibodies in the radioimmunoassay of glucagon. Diabetologia 10, 365 .

Ghatei, M. A. \& Bloom, S. R. (1981). Enteroglucagon in man. In Gut Hormones, vol, 2, pp. 332-338 [S. R. Bloom and J. M. Polak, editors]. Edinburgh: Churchill Livingstone.

Grey, L. V., Garofalo, C., Greenberg, G. R. \& Morin, C. L. (1984). The adaptation of the small intestine after resection in response to free fatty acids. American Journal of Clinical Nutrition 40, 1235-1242.

Hindmarsh, J. T., Kilby, D. \& Roff, B. (1967). Further studies on intestinal transport during semi-starvation. Journal of Physiology 188, 207-218. 
Hooper, C. S. \& Blair, M. (1956). The effect of starvation on epithelial renewal in the rat duodenum. Experimental Cell Research 14, 175-181.

Hopper, A. F., Wannemacher, R. W. \& McGovern, A. (1968). Cell population changes in the intestinal epithelium of the rat following starvation and protein depletion. Proceedings of the Society for Experimental Biology and Medicine 128, 695-698.

Ito, S., Matsubara, Y. \& Shibata, A. (1982). Plasma radioimmunoassayable neurotensin responses to the administration of various nutrients. Tokyo Journat of Experimental Medicine 136, 109-110.

Kapadia, S. \& Baker, S. J. (1976). The effects of alterations in villus shape on the intestinal mucosal surface of the albino rat: the relationship between mucosal surface area and crypts. Digestion 14, 256-268.

Kihl, B., Rokaeus, A., Rosell, S. \& Olbe, L. (1981). Fat inhibition of gastric acid secretion in man and plasma concentrations of neurotensin-like immunoreactivity. Scandinavian Journal of Gastroenterology 16, 513-526.

Long, R. G. \& Bryant, M. G. (1982). Vasoactive intestinal polypeptide. In Radioimmunoassay of Gut Regulatory Peptides, pp. 120-130 [S. R. Bloom and R. G. Long, editors]. London: W. B. Saunders.

McManus, J.P. A. \& Isselbacher, K. J. (1970). Effect of fasting versus feeding on the rat small intestine: morphological, biochemical and functional differences. Gastroenterology 59, 2I 4-221.

Miazza, B. M., Al-Mukhtar, M. Y. T. \& Salmeron, M. (1985). Hyperenteroglucagonaemia and small intestinal mucosal growth after caloric perfusion of glucose in rats. 26, 518524 .

Nemeroff, C. B., Hernandez, D. E., Orlando, R. C. \& Prange, A. J. (1982). Cytoprotective effect of centrally administered neurotensin on stress-induced gastric ulcers. American Journal of Physiology 242, G342-G346.

Robinson, J. W. L. \& Dowling, R. H. (1982). Mechanisms of intestinal adaptations. In Falk Symposium no. 30 , pp. 175-184 [J. W. L. Robinson, R. H. Dowling and E. O. Riecken, editors]. Lancaster: MTP Press.

Rosell, S. (1982). The role of neurotensin in the uptake and distribution of fat. Annals of the New York Academy of Sciences 400, 183-197.

Rosell, S. \& Rokaeus, A. (1979). The effect of ingestion of amino acids, glucose and fat on circulating neurotensinlike immuno-reactivity (NTLI) in man. Acta Physiologica Scandinavica 107, 263-267.

Sagher, F. A. (1988). The effects of variation in dietary fat in early life, with particular reference to the small intestine. PhD Thesis, The Queen's University of Belfast.

Sagher, F. A., Dodge, J. A., Moore, R., McMaster, C. \& McCaughey, G. (1990). Modulation of fluid absorption and the secretory response of rat jejunum to cholera toxin by dietary fat. Gut 31 (In the Press).

Schultzberg, M., Hokfelt, T., Nilsson, G., Terenius L., Rethfeld, J. F., Brown, M., Elde, R., Goldstein, M. \& Said, S. (1980). Distribution of peptide and catecholamine-containing neurons in the gastrointestinal tract of rat and guinea-pig. Neuroscience 5, 689-744.

Shaw, C. \& Buchanan, K. D. (1983). Intact neurotensin NT in human plasma: response to oral feeding. Regulatory Peptides 7, 145-153.

Shaw, C., Watt, P. C. H. \& Buchanan, K. D. (1986). Meal stimulated neurotensin immunoreactivity in plasma following gastric surgery: characterisation with two region specific antisera. Digestion 33, 152-160.

Slavin, G., Sowter, C., Robertson, K., McDermott, S. \& Patton, K. (1980). Measurement in jejunal biopsies by computer-aided microscopy. Journal of Clinical Pathology 33, 254-261.

Solcia, E., Polak, J. M., Pearse, A. G. E., Forssmann, W. G., Larsson, L.-I., Sundler, F., Leechago, J, Grimelius, L., Fumita, T., Creutzfeldt, W., Gepts, W., Falkmer, S., Lefranc, G., Heitz, P., Hage, E., Buchanan, A. M. J., Bloom, S. R. \& Crossman, M. I. (1978). Classification of gastroenteropancreatic endocrine cells. In Gut Hormones, pp. 40 48 [S. R. Bloom and J. M. Polak, editors]. Edinburgh: Churchill Livingstone.

Stanisz, A. M., Befus, D. \& Bienenstock, J. (1986). Differential effects of vasoactive intestinal peptide, substance $\mathrm{P}$ and somatostatin on immunoglobulin synthesis and proliferations by lymphocytes from Peyer's patches, mesenteric lymph nodes and spleen. Journal of Immunology 136, 152-156.

Stanisz, A. M. \& Bienenstock, J. (1986). Neuropeptide modulation of mucosal immunity. Gastroenterology 91 , 486.

Thomson, A. B. R., Keelan, M., Clandinin, M. T. \& Walker, K. (1986). Dietary fat selectively alters transport properties of rat jejunum. Journal of Clinical Investigation $77,279-288$. 